
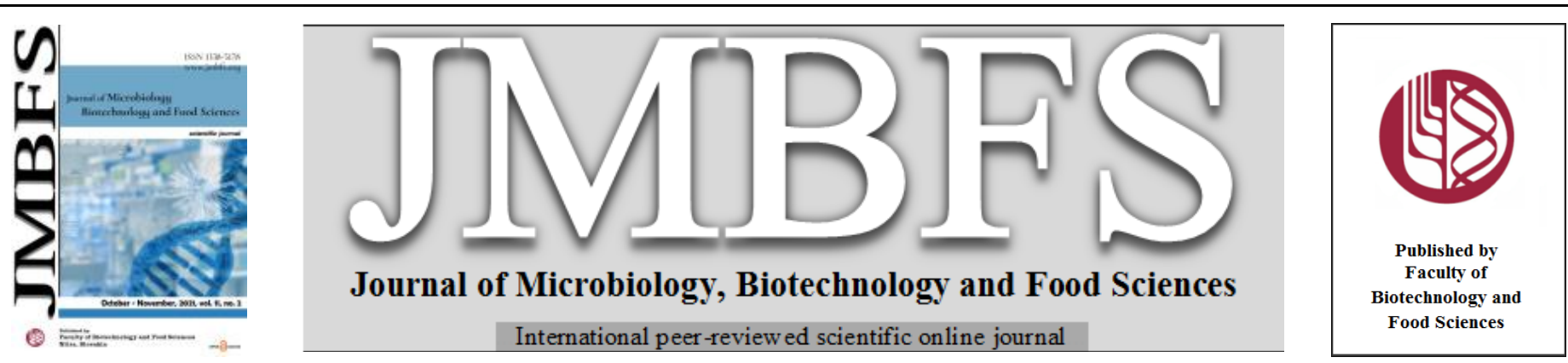

\title{
EVALUATION OF ANTI-INFLAMMATORY EFFECT OF FRUIT PEEL EXTRACTS OF ANNONA SQUAMOSA L. ON MOUSE MODELS OF RHEUMATOID ARTHRITIS
}

\author{
Trang Nguyen Thi ${ }^{1,2}$, Phuong Nhung Tran Thi ${ }^{2}$, Huan Phan Tai ${ }^{1, *}$ \\ Address(es): \\ ${ }^{1}$ Nong Lam University - Ho Chi Minh City, Faculty of Food Science and Technology, Thu Duc district, Ho Chi Minh city 700000, Vietnam. \\ ${ }^{2}$ Industrial University of Ho Chi Minh City, Institute of Biotechnology and Food Technology, Go Vap district, Ho Chi Minh city 700000, Vietnam.
}

*Corresponding author: pthuan@hcmuaf.edu.vn

https://doi.org/10.15414/jmbfs.2075

\section{ARTICLE INFO}

Received 9. 2. 2020

Revised 19. 4. 2021

Accepted 23. 4. 2021

Published 1. 10. 2021

Regular article

OPEN OACCESS $_{\text {A }}$

\begin{abstract}
Rheumatoid arthritis is an autoimmune disease arise as a consequence of exposure to antigens that cause arthritis. A number of herbs have been studied and proven to inhibit arthritis, such as artichoke tea, honey and bee venom. In this study, Freund's Complete Adjuvant (FCA) induced rheumatoid arthritis in mice model was established and evaluated the effect of fruit peel extracts of custard apple, Annona squamosa Linn (AS), on their treatment. After 10 weeks, treated with the peel extracts at high dose, $400 \mathrm{mg} / \mathrm{kg} / \mathrm{day}$, the mice body weight increased from $31.56 \mathrm{~g}$ to $38.00 \mathrm{~g}$, amount of leukocytes decreased from 8.38 to $5.23\left(\mathrm{x} 10^{3} \mathrm{cells} / \mathrm{mm}^{3}\right)$ and ankle joint diameter decreased from 4.63 to $3.95(\mathrm{~mm})$. Histological analysis revealed that effect of fruit peel extracts of AS inhibited invasion of the immune cells into the joint substrate, reduced the fiber formation and restored cartilage structure of synovial membrane. Therefore, AS fruit peel extract prevents inflammatory cell growth of rheumatoid arthritis, increases the number of leukocytes and the body's immunity.
\end{abstract}

Keywords: rheumatoid arthritis; Annona squamosa L.; custard apple; Freund's Complete Adjuvant

\section{INTRODUCTION}

Rheumatoid arthritis (RA) usually occurs in all races and ages. RA is recognized as non-specific inflammatory disease that occurs in joints damaged the synovial membrane, joint cartilage, and subcutaneous cartilage, chronic changes; subsequently, the joints are sticky and deformed. RA causes inflammation, destruction, disfigurement and affects about $1 \%$ of the world's population (Schurgers et al., 2011), the prevalence of RA in children is very high, about 0.008 to 0.266 per 1000 children in every year (Manners \& Bower, 2002). The infiltration of the antigens that cause arthritis triggers an immune response, as $\mathrm{T}$ lymphocytes produce cytokines that stimulate B lymphocytes to produce immunoglobulin complexes deposited in the joint, which damages joint cartilage and leads fibrosis, adhesion and deformity joints (Makay et al., 2013).

There are many synthetic drugs used to treat RA. Recently, the application of folk remedies in traditional Oriental medicine has been recognized as an effectively supportive treatment to prevent and treat rheumatoid arthritis. Annona squamosa, also known as sugar apple or custard apple, is a small tropical tree. The ripe fruit pulp contains around 88.9-95.7 $\mathrm{g}$ calories where the sugar content is $14.58 \%$, amino acid lysine (54-69 mg), carotene (5-7 IU), and ascorbic acid (34.7-42.2 mg) (Morton, 1987). The various chemical constituents isolated from leaves, stems, and roots of the plant include anonaine, aporphine, coryeline, isocorydine, norcorydine, and glaucine (Pandey \& Barve, 2011). Folkloric record reports its use as an insecticidal and antitumor agent (Cheema et al., 1985), antidiabetic (Shirwaikar et al., 2004), antioxidant, antilipidemic (Gupta et al., 2008), and anti-inflammatory agent (Yang et al., 2008) which may be characterized due to the presence of the cyclic peptides (Gajalakshmi et al., 2011). An infusion with 2 handfuls of fresh leaves in $1 \mathrm{~L}$ of water is effective for proper digestion and has antispasmodic activities (Gurib, 2008). The effect of aqueous and organic extracts from defatted seeds of A. squamosa was studied on a rat histolytic tumour cell line. Both organic and aqueous extracts caused significant apoptotic tumour cell death with enhanced caspase-3 activity and downregulation of antiapoptotic genes Bcl-2 and Bcl-xl (Pardhasaradhi et al., 2004). Chen et al. (2012) have recently identified and quantified two main compounds, namely, annonaceous acetogenins from the ethanol extract of $A$. squamosa seeds. The extract was reported to exhibit an antitumor effect against $\mathrm{H}_{22}$ tumor cells line. Bullatacin, a bistetrahydrofuran annonaceous acetogenin was recognized as the most potent inhibitor of the mitochondrial respiratory chain complex I and was observed to be 300 times more active than taxol in vivo (Liaw et al., 2010). Water extracts of A. squamosa leaves also possess antioxidant activity as shown by increased activities of scavenging enzymes such as catalase, superoxide dismutase, reduced glutathione, and malondialdehyde levels present in various tissues (Pardhasaradhi et al., 2004). Administration of the hot-water extracts of leaves of A. squamosa at a dose $300 \mathrm{mg} / \mathrm{kg}$ body weight for 12 weeks to nephrectomized mice resulted in a significant decrease in the plasma urea and creatinine values with even partial restoration to normal values along with a significant rise in the activity of superoxide dismutase. Thus, custard apple shows potential for amelioration of renal failure (Deshmukh \& Patel, 2011). Administration of the aqueous extract of the leaves also improved the activities of plasma insulin and lipid profile and reduced the levels of blood glucose and lipid peroxidation, indicating that the high levels of triglyceride and total cholesterol associated with diabetes can also be significantly managed with the extract (Gupta et al., 2008, Kaleem et al., 2006). Petroleum ether, ethyl acetate and alcoholic extracts of A. squamosa fruit peel were administered orally $(250 \mathrm{mg} / \mathrm{kg}$ body weight) for 21 days showed a significant decrease of blood glucose level and lipid profile on streptozotocin (STZ) induced diabetic mice when compared to untreated diabetic control group (Sharma et al., 2013). A squamosa was also found to promote increased enzymatic (catalase, superoxide dismutase, glutathione peroxidase, and glutathione S-transferase) and nonenzymatic (vitamin $\mathrm{E}$ and ascorbic acid) antioxidants levels and nitric oxide levels in wound tissues for better wound repair mechanism in normal and diabetic mice (Ponrasu et al., 2013). The chloroform, petroleum ether, and ethanol extracts of custard apple also demonstrated important antimicrobial properties against the gram positive microorganisms such as Bacillus subtilis, Bacillus cereus, Bacillus megaterium, Staphylococcus aureus, and Sarcina lutea and the gram negative bacteria such as Escherichia coli, Shigella dysenteriae, Shigella shiga, Shigella flexneri, Shigella sonnei, Salmonella typhi, Pseudomonas aeruginosa, and Klebsiella spp. (Gajalakshmi et al., 2011). Similar results were also reported from the methanolic extracts of custard apple (Aamir et al., 2013). The anti-inflammatory effect of extracts from Annonaceae has been documented in several scientific researches. The freeze-dried fruit extract of Annona Muricata $L$. inhibited the activity of COX-1 and COX-2 cyclooxygenase, which helped to alleviate pain through interaction with opioidergic (O., Olufunsho, Micheal, \& O., 2014). Isolated caryophyllene oxide in the methanolic extract of Annona squamosal $L$. bark suppressed the receptor agonist through inhibiting cyclooxygenase and lipoxygenase and inflammatory centers, which alleviates pain and has anti-inflammatory effect in RA model (Singh et al., 2014) 
Moreover, the presence of alkaloids, flavonoids, steroids, triterpenoids, glycosides, saponins, proteins, resins, glycosides, tannins, lipids in alcohol extracts and triterpenoids, saponins, alkaloids, flavonoids, tannins, resins in aqueous extracts from peels of Annona squamosa after 24 hours achieved an efficacious inhibition of inflammation of $47 \%$ and $72 \%$ in comparison with the effect of sodium diclofenac (Hemalatha \& Satyanarayana, 2009). The essential oil extracted from AS seeds inhibited the growth of $\mathrm{H} 22$ tumor cells in mice through the reduction of interleukin- 6 janus kinase, activation of transcriptiona expression (Chen et al., 2016). These studies indicate that the Annona squamosa extract is a promising drug for the treatment of pain and inflammation in rheumatoid arthritis.

Although many extracts from folk medicinal plants have been studied and proven effectiveness, the anti-inflammatory, analgesic effect of Annona squamosa frui extracts has not been studied. In this study, a model of rheumatoid arthritis induced by FCA was established and the effect of Annona squamosa peel extracts in preventing and treating rheumatoid arthritis was studied.

\section{MATERIAL AND METHODS}

\section{Material}

Custard apple, Annona squamosa L., was harvested in Tay Ninh Province (Vietnam). They have average weight of $200-250 \mathrm{~g}$, average fruit diameter of 7.5 $\mathrm{cm}$. They were washed, peeled and hot air tray-dried at $60^{\circ} \mathrm{C}$ until obtaining moisture content $\leq 12 \%$. The dried peel is powdered, sieved through a sieve of $0.5 \mathrm{~mm}$. After that, the peel powder is packed in a vacuum in PE bags and stored at $0-4^{\circ} \mathrm{C}$ for subsequent experiments

\section{Sample preparation}

The extraction process was carried out based on a previously developed procedure (unpublished results) by using a home-made modified microwave machine (Sanyo, Japan). Peel powder was extracted with $60 \%$ ethanol, solvent/material ratio of $25 / 1(\mathrm{v} / \mathrm{w})$, extraction time of 5 minutes and microwave power of $214 \mathrm{~W}$. The extracts obtained were filtered through Whatman No. 4 filter paper then their TPC was determined.

\section{Analysis of total phenolic content}

Total polyphenol content (TPC) was determined according to the Folin Denis method as described in study of Umesh et al. (2013) with modification. Properly diluted extract (with distilled water) of $100 \mu \mathrm{L}$ was reacted with $1800 \mu \mathrm{L}$ Folin Ciocalteu's reagent (previously diluted 10-fold with distilled water) and incubated at room temperature for $5 \mathrm{~min}$ followed by the addition of $1,200 \mu \mathrm{L}$ of sodium carbonate $(15 \%$, w/v). After 90 min absorbance was measured at $765 \mathrm{~nm}$ at room temperature. The results were expressed as mg gallic acid equivalent per g dry weight (mg GAE/g DW).

\section{Chemicals and reagents}

Freund's Complete Adjuvant (FCA) is a heat-killed and desiccated Mycobacterium tuberculosis solution that is emulsified in mineral oil, used as an immune enhancer. FCA is provided by Sigma Santa Clara, CA (D2354, SigmaAldrich, USA).

Mobic belongs to oxicam, a class of non-steroidal anti-inflammatory drug, analgesic, and anti-osteoarthritis. It is used as positive control (or reference drug) in this study and is dissolved in distilled water. Mobic is supplied by Boehringer Ingelheim Espana S.A.

Folin-Ciocalteu reagent was purchased from Merck (Germany). A trolox (6hydroxy-2,5,7,8-tetramethylchroman-2-carboxylic acid, purity: 97\%) reagent was purchased from Sigma-Aldrich (USA) and all other chemicals and organic solvents were analytical grade.

\section{Animals and experimental design}

The 6-week-old Swiss Albino male mice, weighing 32-34g, were purchased from the Pasteur Institute of Ho Chi Minh City (Vietnam). All mice have not been mated. Mice were kept at the Animal House of the University of Industry at Ho Chi Minh City at $25 \pm 2{ }^{\circ} \mathrm{C}$ and humidity of $55 \pm 5 \%$, light mode: day/dark $=16 \mathrm{~h}$ light/ $8 \mathrm{~h}$ dark per day for at least a week before the test. Mice are kept in cages and are allowed freely access to foods and drinks. All welfare and experimental procedures of animals are conducted in accordance with the guidelines for care and use of laboratory animals. The experimental procedure was in strictly compliance with Declaration of Helsinki (Carlson et al., 2004).

Mice were treated with test agents started on day 7 (since the mouse was picked up). Orally administered and inject dosing regimens were used for mice. Briefly, mice were divided into several groups:

Control group (Normal): 5 mice in this group, they were freely access to water and food for 12 days.
Rheumatoid arthritis model group (FCA): 25 mice in this group, they were injected with single dose of $0.1 \mathrm{ml}$ FCA per mouse. Then, they were maintained for next 12 days (Lee et al., 2004).

After successfully established rheumatoid arthritis models (12 days), the mice of group FCA which have arthritis were divided into 5 groups: 5 mice with RA/groups, mice treated for 10 weeks.

(i) Negative control group (Untreated): 5 mice in this group, they were freely access to water and food for 10 weeks.

(ii) Positive control group (Mobic): 5 mice in this group, they were orally treated with $1 \mathrm{mg}$ mobic/kg body weight twice per day for 10 weeks (Lee et al. 2004).

(iii) Fruit peel AS extract-low dose, $200 \mathrm{mg} / \mathrm{kg} / \mathrm{day}$ (ASL): 5 mice in this group, they were orally treated with $200 \mathrm{mg}$ fruit peel extract AS/kg body weight twice per day for 10 weeks.

(iv) Fruit peel AS extract-medium dose, $300 \mathrm{mg} / \mathrm{kg} /$ day (ASM): 5 mice in this group, they were orally treated with $300 \mathrm{mg}$ fruit peel extract AS/kg body weight twice per day for 10 weeks.

(v) Fruit peel AS extract-high dose, $400 \mathrm{mg} / \mathrm{kg} /$ day $(\mathrm{ASH}): 5$ mice in this group, they were orally treated with $400 \mathrm{mg}$ fruit peel extract $\mathrm{AS} / \mathrm{kg}$ body weight twice per day for 10 weeks (Zhang et al., 2014).

During experimental period, ankle joint diameter, feet temperature, the changes of body weights, peripheral leukocyte concentrations, and histological analysis were measured.

\section{Measurement of body weight, peripheral leukocytes concentration}

In chosen time point, all experimental animals were fasted overnight to reduce the differences of feeding. The body weights were measured by electronic scale, and the change of body weights of mice was recorded. The results were presented as mean and standard deviation. Then, mice were anesthetized using ketamine xylazine $(24 \mathrm{mg} / \mathrm{kg}$ b.w) intramuscular and then bloods were collected from tail veins into the anti-coagulant $\mathrm{K}_{2}$ EDTA coated tubes. Blood samples were analyzed for leukocyte concentration. The body weights and the peripheral tota leukocyte count of the mice in the arthritis-induced side was measured on day 0 (before onset of arthritis) and days 3,6,9 and 12 (after onset of arthritis). Next, on week 4,6,8 and 10 (after starting to drink the extract).

\section{Ankle joint temperature and diameter}

Arthritis rises and leads to elevation of the temperature in joint region. The temperature of the joints can be used to estimate the degree of inflammation. Room temperature is maintained at ambient temperature of about $26^{\circ} \mathrm{C}$. The ankle joint temperature is checked daily from the day before the injection of the arthritis medication and during the course of treatment (Can et al., 2016).

The ankle joint diameter is measured by a dedicated Mitutoyo 500-182-30 (0$200 \mathrm{~mm} / 0.01 \mathrm{~mm}$ ) electronic workhorse, the largest diameter measured at the righ ankle joint, measured at time-points: $0,3,6,9,12$ days and 4, 6, 8, 10 weeks from the day of the injection of the arthritis medication. The index of ankle joint at each study site was measured in millimeters (mm) (Calado et al., 2015).

Histopathological assessment of ankle joint:

At the end of experiment, all experimental mice were euthanized by carbon dioxide inhalation. The ankle joints were collected and fixed in $10 \%$ formalin Samples were stained with Hematoxylin and Eosin (H \& E) dyes and slides were evaluated under light microscope (Olympus LX70, Olympus, Tokyo, Japan). Assessment of degeneration was based on anatomical histogram, traumatic score (Al-Saffar et al., 2009, Janusz et al., 2002).

\section{Statistical analysis}

Statistical analysis was performed using Statgraphics Centurion XVI software (Statpoint Technologies Inc., Warrenton, Virginia, USA). The data were presented as mean \pm standard deviation. Differences between means of different groups were analyzed using ANOVA variance analysis followed with multiple range tests, the criterion of statistical significance was set as $\mathrm{p}<0.05$.

\section{RESULTS AND DISCUSSION}

\section{Changes of body weight}

The body weights of normal and arthritis mice were significantly altered after 12 days. Figure 1 shows that body weights of normal mice were gradually increased from $32.34 \pm 0.7 \mathrm{~g}$ to $33.84 \pm 0.2 \mathrm{~g}$, while the body weight of rheumatoid arthritis mice were dramatically changed. In the first three days, mice weights were dropped sharply (from $33.85 \pm 0.3 \mathrm{~g}$ to $30.12 \pm 0.4 \mathrm{~g}$ ). They increased slightly in the following days to $32.11 \pm 0.3 \mathrm{~g}$ (day 12). According to Billiau \& Matthys, (2001) when mice were injected with $\mathrm{FCA}, \mathrm{CD}_{4}{ }^{+} \mathrm{T}$-cells infiltrate into the synovial membrane and initiate the inflammatory process. Lymphocyte $\mathrm{T}$ produces cytokines (IFN- $\alpha$, GM-CSF) activating macrophages to increase HLA and stimulates B-cell proliferation, differentiates into plasma cells that produce antibodies. TNF- $\alpha$ stimulates the production of prostaglandin E2 causing 
vasodilation. At inflammation, oxidation increases oxygen, reduces $\mathrm{pH}$ and disturbs metabolism of glucide, lipid, protein (Billiau \& Matthys, 2001). The finding was agree with results from Halliday et al. (2004) study, in which the weight gain of mice in normal group was higher than those of FCA treated group (Halliday et at., 2004).

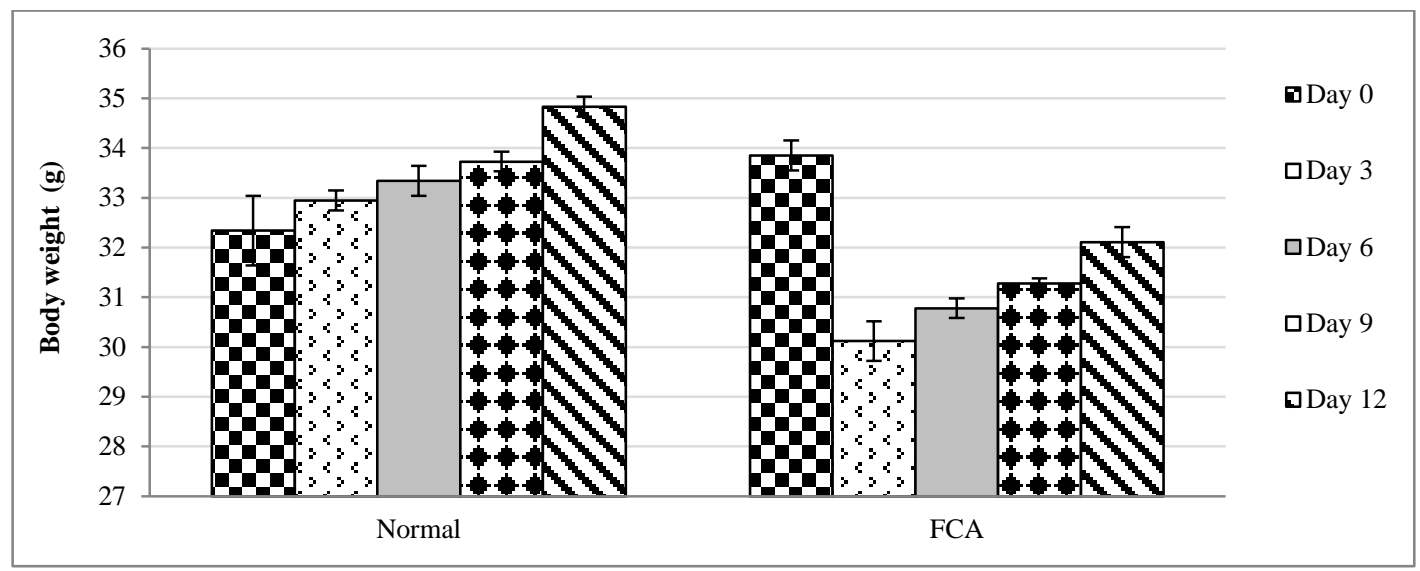

Figure 1 Body weight in control mice and CFA mice during 12 days after adjuvant injection. Values are the mean \pm SD of measurements, $\mathrm{p}<0.05$ each point at the respective time of each group.

The body weight of mice treated with AS extracts increased significantly compared to untreated mice (Figure 2). In this study, the AS extract contains a large number of polyphenolic compounds with the TPC values $95.32 \pm 1.71 \mathrm{mg}$ GAE $/ \mathrm{g} \mathrm{DW}$. The mice treated with AS extract at dose $200 \mathrm{mg} / \mathrm{kg}, 300 \mathrm{mg} / \mathrm{kg}$ and $400 \mathrm{mg} / \mathrm{kg}$ increased weight from $31.56 \pm 0.3 \mathrm{~g}$ to $38.00 \pm 0.1 \mathrm{~g}, 31.55 \pm 0.3 \mathrm{~g}$ to $38.24 \pm 0.3 \mathrm{~g}$ and $31.51 \pm 0.3 \mathrm{~g}$ to $39.23 \pm 0.2 \mathrm{~g}$ respectively. The increase in body weight of mice treated with $400 \mathrm{mg} / \mathrm{kg}$ was similar to the increase in body weigh of mice treated with mobic $(40.01 \pm 0.1 \mathrm{~g})$ (reference drug, $p<0.05)$. According to Yoon \& Baek (2005), polyphenols are transported through the protein channel of the cell membrane to the inflammatory site, inhibiting the activity of the enzyme cyclooxygenase and lipoxygenase, activating the reaction against inflammatory agents that reduce cytokine, TNF- $\alpha$, IL-6, stop working. of nuclear factor- $\kappa \mathrm{B}$ $(\mathrm{NF}-\kappa \mathrm{B})$, inhibiting prostaglandin formation (PG). COX converts AA to PG and lipoxygenase (LOX) into leukotrienes. Phenol compounds inhibit the path of cyclooxygenase and 5-lipoxygenase to reduce arachidonic acid. When the inflammatory pathways are inhibited, the physiological activity of the body returns to normal, physical metabolism in the body increases (Yoon \& Baek 2005)

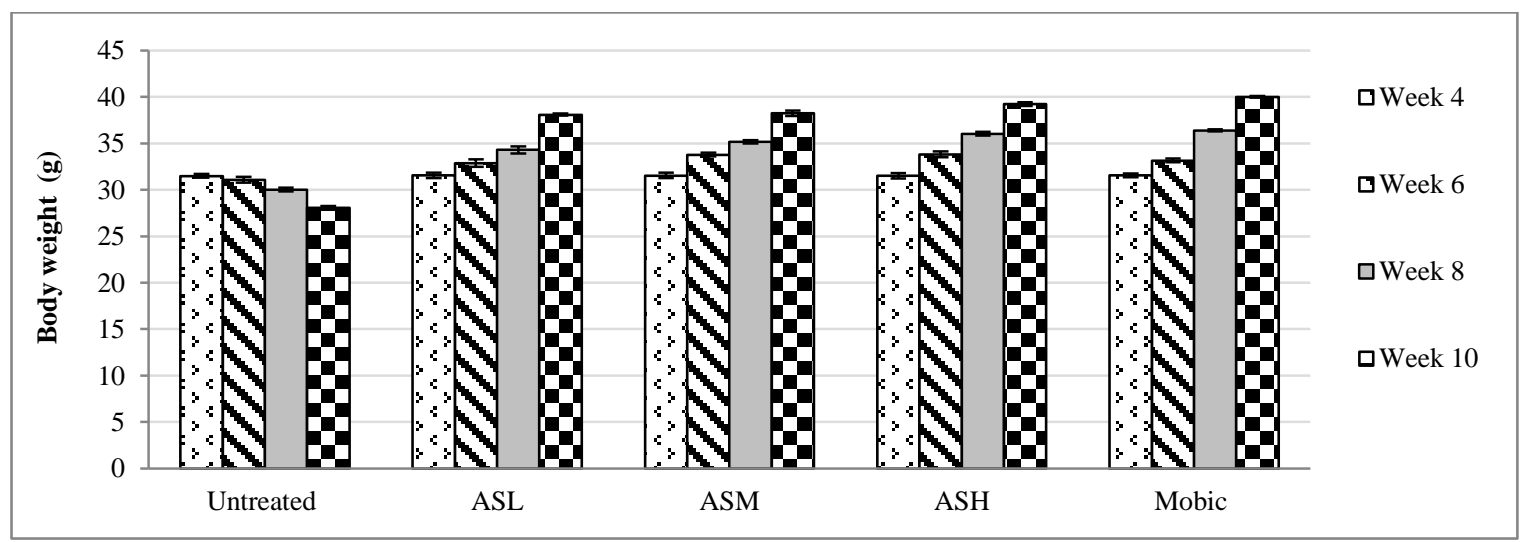

Figure 2 Effects of AS on mean body weight over time 10 weeks ( $=5$, mean \pm SEM). Changes in body weights were assessed at each point time $(\mathrm{p}<0.05)$ with results between groups at week 10 .

\section{Changes of peripheral leukocytes}

Amount of total peripheral leukocytes of the mice in rheumatoid arthritis group were higher than those of normal mice $\left(4.5 \times 10^{3}\right.$ versus $5.88 \times 10^{3}$ cells $\left./ \mathrm{mm}^{3}\right)$ after 12 days. It is found in Table 1 that total lymphocytes, monocytes, granulocytes of rheumatoid arthritis models noticeably increased after 12 days $(5.42 \pm 0.02$, $0.086 \pm 0.005,0.033 \pm 0.002 \times 10^{3}$ cells $/ \mathrm{mm}^{3}$, respectively), while the number of total types leukocytes of normal group were steady during experiment (Table 2).

Table 1 Change of peripheral leukocytes of normal and rheumatoid arthritis mice (mean \pm standard deviation).

\begin{tabular}{|c|c|c|c|c|c|}
\hline \multirow[t]{2}{*}{ Group } & \multicolumn{5}{|c|}{ Peripheral Leukocytes $\left(\mathbf{1 0}^{3}\right.$ cells/mm $\left.\mathbf{m}^{3}\right)$} \\
\hline & Day 0 & Day 3 & Day 6 & Day 9 & Day 12 \\
\hline Normal & $4.52 \pm 0.09^{\mathrm{a}}$ & $4.58 \pm 0.13^{\mathrm{a}}$ & $4.56 \pm 0.16^{\mathrm{a}}$ & $4.56 \pm 0.11^{\mathrm{a}}$ & $4.52 \pm 0.13^{\mathrm{a}}$ \\
\hline FCA & $4.55 \pm 0.09^{\mathrm{a}}$ & $6.12 \pm 0.26^{\mathrm{b}}$ & $6.86 \pm 0.16^{\mathrm{b}}$ & $7.21 \pm 0.06^{\mathrm{c}}$ & $8.38 \pm 0.07^{\mathrm{d}}$ \\
\hline
\end{tabular}

a,b,c,d Different letters in same column indicate significant differences among different groups $(\mathrm{p}<0.05)$.

Table 2 Variation of different types of peripheral leukocytes of normal and rheumatoid arthritis mice (mean \pm standard deviation)

\begin{tabular}{|c|c|c|c|c|c|c|}
\hline \multirow[t]{2}{*}{ Group } & \multicolumn{2}{|c|}{$\begin{array}{c}\text { Lymphocytes } \\
\left(\times 10^{3} \text { cell } / \mathbf{m m}^{3}\right)\end{array}$} & \multicolumn{2}{|c|}{$\begin{array}{c}\text { Monocytes } \\
\left(\mathbf{x 1 0}^{3} \text { cell } / \mathbf{m m}^{3}\right)\end{array}$} & \multicolumn{2}{|c|}{$\begin{array}{l}\text { Granulocytes } \\
\left(\times 10^{3} \text { cell } / \mathrm{mm}^{3}\right)\end{array}$} \\
\hline & Normal & FCA & Normal & FCA & Normal & FCA \\
\hline Day 0 & $4.09 \pm 0.07^{\mathrm{a}}$ & $4.06 \pm 0.06^{\mathrm{a}}$ & $0.057 \pm 0.003^{\mathrm{a}}$ & $0.058 \pm 0.003^{\mathrm{a}}$ & $0.116 \pm 0.001^{\mathrm{a}}$ & $0.119 \pm 0.003^{\mathrm{a}}$ \\
\hline Day 6 & $4.19 \pm 0.17^{\mathrm{a}}$ & $5.55 \pm 0.09^{b}$ & $0.059 \pm 0.003^{\mathrm{a}}$ & $0.088 \pm 0.006^{\mathrm{a}}$ & $0.112 \pm 0.004^{\mathrm{a}}$ & $0.034 \pm 0.002^{b}$ \\
\hline Day 9 & $4.18 \pm 0.08^{\mathrm{a}}$ & $5.49 \pm 0.09^{\mathrm{bc}}$ & $0.059 \pm 0.005^{\mathrm{a}}$ & $0.087 \pm 0.005^{\mathrm{a}}$ & $0.117 \pm 0.003^{\mathrm{a}}$ & $0.033 \pm 0.001^{\mathrm{b}}$ \\
\hline Day 12 & $4.16 \pm 0.07^{\mathrm{aA}}$ & $5.42 \pm 0.02^{\mathrm{cB}}$ & $0.058 \pm 0.004^{\mathrm{aA}}$ & $0.086 \pm 0.005^{\mathrm{aB}}$ & $0.119 \pm 0.003^{\mathrm{aA}}$ & $0.033 \pm 0.002^{\mathrm{bB}}$ \\
\hline
\end{tabular}

${ }_{\mathrm{a}, \mathrm{b}, \mathrm{c}}$ Values with different letters in one group at different time points were significantly different $(\mathrm{p}<0.05)$.

${ }^{A}$ B Values with different letters between groups at day 12 were significantly different $(\mathrm{p}<0.05)$. 
The arthritis is triggered by $\mathrm{CD}_{4}{ }^{+} \mathrm{T}$-cells invasion in the synovial membrane Lymphocyte $\mathrm{T}$ produces cytokines activating macrophage that increase the expression of HLA molecules, stimulate lymphocyte B cells to proliferate and differentiate into antibody-producing cells. FCA affects the immune system, changes the leukocyte, increases phagocytosis, excretes cytokines, and proliferates $\mathrm{CD}_{4}{ }^{+}$(Pearson, 1956). Mycobacterium in FCA attracts macrophages that increase the immune response. In the first stage of inflammation, neutrophils, and macrophages move to inflammatory region. Then, large amounts of monocytes transfer from the blood into the tissue, change the characteristic, enlarged, increase the amoeba movement toward the tissue damage. These cells secrete cytokines, interferons, vascular endothelial growth factors (VEGFs) that promote inflammation (McInnes \& Schett, 2011).

\begin{tabular}{|c|c|c|c|c|c|}
\hline \multirow{2}{*}{ Group } & \multicolumn{5}{|c|}{ Total peripheral leukocytes $\left(\times 10^{3}\right.$ cells $\left./ \mathrm{mm}^{3}\right)$} \\
\hline & Untreated & ASL & ASM & ASH & Mobic \\
\hline Week 4 & $31.39 \pm 0.29^{\mathrm{a}}$ & $31.56 \pm 0.29^{\mathrm{a}}$ & $31.55 \pm 0.3^{\mathrm{a}}$ & $31.51 \pm 0.33^{\mathrm{a}}$ & $31.57 \pm 0.18^{\mathrm{a}}$ \\
\hline Week 6 & $31.08 \pm 0.29^{\mathrm{a}}$ & $32.86 \pm 0.28^{\mathrm{b}}$ & $33.78 \pm 0.22^{\mathrm{b}}$ & $33.82 \pm 0.32^{\mathrm{b}}$ & $33.16 \pm 0.17^{\mathrm{b}}$ \\
\hline Week 8 & $31.01 \pm 0.16^{\mathrm{b}}$ & $34.29 \pm 0.4^{\mathrm{c}}$ & $35.16 \pm 0.22^{\mathrm{c}}$ & $36.02 \pm 0.18^{\mathrm{c}}$ & $36.39 \pm 0.12^{\mathrm{c}}$ \\
\hline Week 10 & $28.07 \pm 0.24^{\mathrm{cA}}$ & $38.09 \pm 0.12^{\mathrm{dB}}$ & $38.24 \pm 0.36^{\mathrm{dB}}$ & $39.23 \pm 0.23^{\mathrm{dC}}$ & $40.01 \pm 0.13^{\mathrm{dD}}$ \\
\hline
\end{tabular}

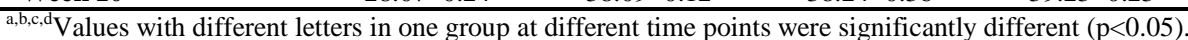

${ }_{A}^{A}, B, C, D$ Values with different letters between groups at week 10 were significantly different $(\mathrm{p}<0.05)$.

\begin{tabular}{|c|c|c|c|c|c|c|}
\hline Index & Time & Untreated & ASL & ASM & ASH & Mobic \\
\hline \multirow{4}{*}{$\begin{array}{l}\text { Lymphocytes } \\
\left(\mathbf{x 1 0}^{3} \text { cell } / \mathbf{m m}^{3}\right)\end{array}$} & Week 4 & $5.57 \pm 0.23^{\mathrm{a}}$ & $5.27 \pm 0.14^{\mathrm{a}}$ & $5.26 \pm 0.12^{\mathrm{a}}$ & $5.27 \pm 0.08^{\mathrm{a}}$ & $5.26 \pm 0.08^{\mathrm{a}}$ \\
\hline & Week 6 & $5.53 \pm 0.15^{\mathrm{a}}$ & $5.11 \pm 0.23^{\mathrm{ab}}$ & $5.09 \pm 0.1^{\mathrm{b}}$ & $4.68 \pm 0.17^{\mathrm{b}}$ & $4.63 \pm 0.16^{\mathrm{b}}$ \\
\hline & Week 8 & $5.51 \pm 0.23^{\mathrm{a}}$ & $4.97 \pm 0.19^{c}$ & $4.95 \pm 0.08^{\mathrm{c}}$ & $4.53 \pm 0.12^{c}$ & $4.45 \pm 0.12^{\mathrm{c}}$ \\
\hline & Week 10 & $5.41 \pm 0.06^{\mathrm{bA}}$ & $4.65 \pm 0.21^{\mathrm{dB}}$ & $4.93 \pm 0.14^{\mathrm{dC}}$ & $4.18 \pm 0.17^{\mathrm{dD}}$ & $4.06 \pm 0.1^{\mathrm{dD}}$ \\
\hline \multirow{4}{*}{ 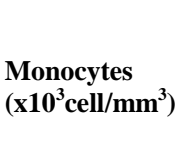 } & Week 4 & $0.092 \pm 0.011^{\mathrm{a}}$ & $0.093 \pm 0.009^{\mathrm{a}}$ & $0.091 \pm 0.011^{\mathrm{a}}$ & $0.091 \pm 0.007^{\mathrm{a}}$ & $0.092 \pm 00.9^{\mathrm{a}}$ \\
\hline & Week 6 & $0.09 \pm 0.008^{\mathrm{a}}$ & $0.089 \pm 0.007^{\mathrm{ab}}$ & $0.087 \pm 0.007^{\mathrm{b}}$ & $0.076 \pm 0.013^{\mathrm{ab}}$ & $0.074 \pm 0.008^{\mathrm{ab}}$ \\
\hline & Week 8 & $0.087 \pm 0.006^{\mathrm{a}}$ & $0.075 \pm 0.009^{\mathrm{bc}}$ & $0.073 \pm 0.015^{\mathrm{bc}}$ & $0.068 \pm 0.017^{\mathrm{bc}}$ & $0.061 \pm 0.019^{\mathrm{bc}}$ \\
\hline & Week 10 & $0.083 \pm 0.007^{\mathrm{aA}}$ & $0.068^{\mathrm{BC}} \pm 0.015^{\mathrm{dBC}}$ & $0.065 \pm 0.016^{\mathrm{dBC}}$ & $0.055 \pm 0.012^{\mathrm{dCD}}$ & $0.052 \pm 0.011^{\mathrm{dE}}$ \\
\hline \multirow{4}{*}{$\begin{array}{l}\text { Granulocytes } \\
\left(\times 10^{3} \text { cell } / \mathbf{m m}^{3}\right)\end{array}$} & Week 4 & $0.347 \pm 0.004^{\mathrm{a}}$ & $0.348 \pm 0.004^{\mathrm{a}}$ & $0.347 \pm 0.003^{\mathrm{a}}$ & $0.347 \pm 0.003^{\mathrm{a}}$ & $0.346 \pm 0.009^{\mathrm{a}}$ \\
\hline & Week 6 & $0.346 \pm 0.005^{\mathrm{a}}$ & $0.342 \pm 0.005^{\mathrm{ab}}$ & $0.33 \pm 0.004^{\mathrm{b}}$ & $0.335 \pm 0.002^{\mathrm{a}}$ & $0.276 \pm 0.003^{\mathrm{b}}$ \\
\hline & Week 8 & $0.342 \pm 0.005^{\mathrm{a}}$ & $0.339 \pm 0.003^{\mathrm{c}}$ & $0.321 \pm 0.006^{\mathrm{c}}$ & $0.262 \pm 0.003^{\mathrm{b}}$ & $0.198 \pm 0.003^{\mathrm{c}}$ \\
\hline & Week 10 & $0.34 \pm 0.001^{\mathrm{aA}}$ & $0.297 \pm 0.009^{\mathrm{dBC}}$ & $0.28 \pm 0.001^{\mathrm{dBC}}$ & $0.129 \pm 0.004^{\mathrm{cDE}}$ & $0.119 \pm 0.001^{\mathrm{dDE}}$ \\
\hline
\end{tabular}

a,b,c,d Values with different letters in one group at different time points were significantly different $(\mathrm{p}<0.05)$.

$\mathrm{A}, \mathrm{B}, \mathrm{C}, \mathrm{D}, \mathrm{E}$ Values with different letters between groups at $10^{\text {th }}$ week were significantly different $(\mathrm{p}<0.05)$

Leukocytes are a major component of the body's immune system. Indications for a leukocytes count include infectious and inflammatory diseases. Pathogenic micro-organisms invading the body stimulate the immune system resulting in increased leukocytes. Inhibition of inflammation by AS extract is also associated with reversal of increased levels leukocytes. Changes of peripheral leucocytes in mice treated with AS extract and mobic were significantly different from untreated mice. In the treatment group with 200,300 , and $400 \mathrm{mg} / \mathrm{kg}$ AS extracts, peripheral leukocytes returned to a baseline level $(6.09 \pm 0.12,6.04 \pm 0.36$, $5.23 \pm 0.23 \times 10^{3}$ cells $/ \mathrm{mm}^{3}$, respectively) in $10^{\text {th }}$ week, whereas in the untreated group the peripheral leukocytes was increase $\left(10.37 \pm 0.24 \times 10^{3}\right.$ cells $\left./ \mathrm{mm}^{3}\right)($ Tables $3)$. Rheumatoid arthritis mice treated with mobic reduced peripheral leukocytes to $5.01 \pm 0.13 \times 10^{3}$ cells $/ \mathrm{mm}^{3}$ (reference drug, $p<0.05$ ). This variation is similar to that of lymphocytes (ASH 4.98 \pm 0.17 ), monocytes (ASH $0.055 \pm 0.012$ ), granulocytes (ASH 0.129 \pm .0 .004 ) compared to the untreated group (lymphocytes $10.21 \pm 0.06$, monocytes $0.083 \pm 0.007$, granulocytes $0.34 \pm 0.001$ ) (Tables 4 ). This result is consistent with research finding of Paul et al. (2018)

Chronic inflammation occurs because leukocytes activate the cytokine secretion pathways. Cytokine is the major mediator of intracellular metabolism required for an integrated response to a series of stimuli during immune and inflammatory processes. Large amounts of flavonoids, polyphenols, inhibit the expression of inflammatory cytokines, combined to enhance anti-inflammatory cytokines (Tunon et al., 2009). Phenolic compounds of AS peel extracts have immunosuppressive properties, which reduces number of leukocytes (lymphocytes, monocytes, granulocytes). Phenolic compounds stimulate cell growth and IL-10 production (anti-inflammatory cytokine). In the mice treated with $400 \mathrm{mg} / \mathrm{kg}$, good immunosuppressive effect supported the leukocytes to reach the healthy (Noble $\boldsymbol{\&}$ Balfour, 1996).

\section{Change of temperature and diameter of the ankle joint}

Table 5, the skin surface temperature at the hind limb arthritis-induced side showed a significant increase in temperature when compared to the control $(\mathrm{p}<0.01$ and $\mathrm{p}<0.05$, respectively). The mean average temperature difference between normal group and FCA group was found to be $27.4{ }^{\circ} \mathrm{C}$ and $30.4{ }^{\circ} \mathrm{C}$ respectively. This result is similar to those reported by many authors (Snekhalatha et al., 2013).

Table 5 Changes of ankle joint temperature of normal and rheumatoid arthritis mice (mean \pm standard deviation).

\begin{tabular}{lcccc}
\hline \multirow{2}{*}{ Group } & \multicolumn{4}{c}{ Temperature ( ${ }^{0}$ C) } \\
\cline { 2 - 5 } Normal & Day 0 & Day 3 & Day 6 & Day 9 \\
\cline { 2 - 5 } FCA & $27.3 \pm 0.18^{\mathrm{a}}$ & $27.8 \pm 0.15^{\mathrm{a}}$ & $27.6 \pm 0.15^{\mathrm{a}}$ & $27.5 \pm 0.22^{\mathrm{a}}$ \\
\end{tabular}

$\frac{{ }_{a, b, c, d}}{{ }^{A}, \mathrm{~A}}$ alues with different letters in one group at different time points were significantly different $(\mathrm{p}<0.05)$.

${ }^{\mathrm{A}, \mathrm{B}}$ Values with different letters between groups at day 12 were significantly different $(\mathrm{p}<0.05)$.

Figure 3 shows differences in the diameter of hind limbs of the mice. After 12 days, the ankle joint diameter of normal group was unchanged ( 0 day is $3.2 \pm 0.1$ $\mathrm{mm}$ and up to 12 days is $3.21 \pm 0.1 \mathrm{~mm}$ ). In the FCA group, after 12 days of injection, the ankle joint diameter significantly $(\mathrm{p}<0.05)$ increased from $3.19 \mathrm{~mm}$ to $5.26 \mathrm{~mm}$ in the first 3 days, and after that slightly decreased to $4.63 \mathrm{~mm}$. The mean circumference of the hind limbs inflamed the dense mononuclear inflammatory infiltration comprising of predominantly lymphocytes and histiocytes. The difference in morphology of ankle between mice in the norma and FCA group was consistent with those reported by Snekhalatha et al. (2013). FCA is an antigen that activates macrophages, increases expression of MHC class II and B7 molecules on cell membranes, increases cytokine secretion, releases chemical intermediates, disturbs circulation, activation of $\mathrm{TH}$ cells, metabolic disorder in mouse bodies. This is the reason for the enlarged ankle joint after FCA injection. Inflammatory agents cause damage to cells, that release chemica intermediates and cause circulatory disorders, metabolism, make inflammation more progressive (Stils, 2005).

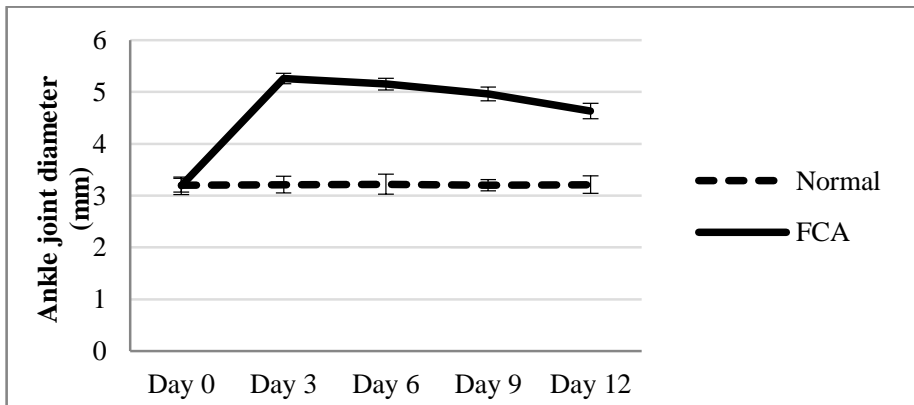

Figure 3 Ankle diameters of rheumatoid arthritis (FCA) and normal mice during 12 days after injection. Changes in ankle diameters were assessed at each point time $(\mathrm{p}<0.05)$ with results between groups. 
Table 6 Changes of ankle joint temperature of rheumatoid arthritis mice treated with AS peel extracts.

\begin{tabular}{|c|c|c|c|c|c|}
\hline \multirow{2}{*}{ Group } & \multicolumn{5}{|c|}{ Temperature $\left({ }^{0} \mathrm{C}\right)$} \\
\hline & Untreated & ASL & ASM & ASH & Mobic \\
\hline Week 4 & $30.2 \pm 0.19^{\mathrm{a}}$ & $30.5 \pm 0.21^{\mathrm{a}}$ & $30.3 \pm 0.17^{\mathrm{a}}$ & $30.4 \pm 0.2^{\mathrm{a}}$ & $30.5 \pm 0.19^{\mathrm{a}}$ \\
\hline Week 6 & $30.1 \pm 0.17^{\mathrm{a}}$ & $29.5 \pm 0.14^{\mathrm{b}}$ & $29.9 \pm 0.22^{\mathrm{b}}$ & $29.4 \pm 0.17^{\mathrm{b}}$ & $29.6 \pm 0.16^{\mathrm{b}}$ \\
\hline Week 8 & $29.8 \pm 0.22^{\mathrm{ab}}$ & $28.8 \pm 0.15^{\mathrm{c}}$ & $29.1 \pm 0.31^{\mathrm{c}}$ & $28.3 \pm 0.15^{\mathrm{c}}$ & $28.4 \pm 0.16^{\mathrm{c}}$ \\
\hline Week 10 & $29.5 \pm 0.16 b^{A}$ & $28.2 \pm 0.21^{\mathrm{dB}}$ & $28.1 \pm 0.21^{\mathrm{dB}}$ & $27.6 \pm 0.2^{\mathrm{dC}}$ & $27.5 \pm 0.17^{\mathrm{dC}}$ \\
\hline
\end{tabular}

${ }^{a, b, c, d}$ Values with different letters in one group at different time points were significantly different $(p<0.05)$.

${ }^{A, B, C}$ Values with different letters between groups at week 10 were significantly different $(\mathrm{p}<0.05)$.

Temperature of the ankle joint of rheumatoid arthritis mice treated with AS extract was gradually reduced (Table 6). After 10 weeks, the temperatures of mice treated with AS extract and Mobic groups returned to their normal state (ASL: $28.2^{\circ} \mathrm{C}$, ASM: $28.1^{\circ} \mathrm{C}$, ASH: $27.6^{\circ} \mathrm{C}$ and Mobic: $27.5^{\circ} \mathrm{C}$ ) and were lower than those of the untreated group $\left(29.5^{\circ} \mathrm{C}\right)$.

There is a change in diameter of ankle joint under the effect of AS fruit peel extracts (Figure 4). The ankle diameter of untreated mice increased significantly during the experimental period, from $4.63 \pm 0.17 \mathrm{~mm}$ at Week 4 and increased to $5.08 \pm 0,13 \mathrm{~mm}$ at the end of experiment $(\mathrm{p}<0.05)$. In contrast, all mice ankles in groups treated with AS extracts and mobic had significantly reduced in diameters (4.18 \pm 0.12 ASL, $4.01 \pm 0.11$ ASM, $3.95 \pm 0.12$ ASH and $3.72 \pm 0.19 \mathrm{~mm}$ Mobic, $\mathrm{p}<0.05)$

Polyphenols help to improve damaged areas and have antimicrobial properties (Manach et al., 2004). The chemical structure of polyphenols affects the conjugation with methyl, sulfate or glucuronide groups, and biological properties (antioxidant activity, interaction with cellular receptors, enzymes and other properties) (Tarahovsky, Kim, Yagolnik, \& Muzafarov, 2014). Polyphenols are involved in activation of cellular responses against inflammatory agents by inhibiting inflammatory enzymes such as cyclooxygenase, lipoxygenase, and cytokine depletion, such as TNF- $\alpha$ and IL- 6 growth factors, of the nuclear factor$\kappa \mathrm{B}(\mathrm{NF}-\kappa \mathrm{B})$. The release of AA (arachidonic acid) from the phospholipid membrane is triggered by the activity of a highly cytosolic phospholipase A2 (cPLA2). Phenolic compounds inhibit cyclooxygenase and 5-lipoxygenase pathways, and reduce the release of arachidonic acid (Hussain et al., 2016) When inflammatory pathways are completely suppressed by oral extraction, the inflammatory reaction tends to decrease, and joint tissue structure is recovered.

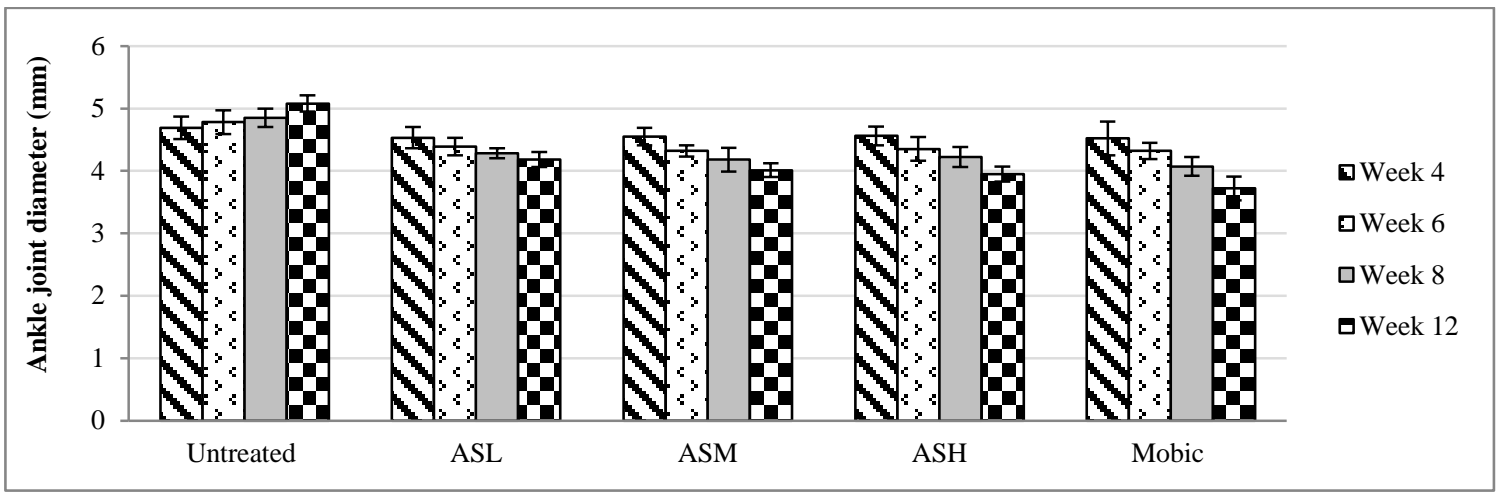

Figure 4 Effects of AS peel extracts on ankle joint diameter of rheumatoid arthritis mice over time of 10 weeks ( $n=5$, mean \pm SEM).

\section{Changes of morphology and histology of the ankle joint}

After 12 days of FCA injection, the morphology of ankle joints and leg swelling of the normal and FCA mice were significantly different (Figure 5A). In normal mice group, ankle joint tissues have cartilage capsule containing oriented cartilage cells and well order arrangement. In the outer layer of cartilage capsule has fibrous and elastic fibers with fewer fibrous cells than in the inner layer. In the untreated mice group appear thick membranous joints and inflammatory cells. The fibroblasts are more proliferated, form fibrous cartilage that covers the cartilage's surface from the nourishment source. There is an accumulation of joint fluid and mononuclear cells in joint space (Figure 5b). Histological analysis showed that cartilage in the ankle joint developed to chronic inflammation with poor prognosis during treatment. This finding is identical with the results from study of Shen et al. (2013).

When FCA causes inflammation, leukocytes enter tissue and triggers inflammation. Lymphocyte $\mathrm{T}$ produces cytokines, stimulates neutrophil transport into the synovial membrane. Cytokines, chemokines, and lipid-mediated inflammatory mediators (prostaglandins, leukotrienes) increase chondrocyte's catabolic activity, release protein-digesting enzymes (aggrecanases, matrix metalloproteinases), which destroy cartilage, basic substance, and cause inflammation of the synovium and exudates into the joints (Billiau \& Matthys, 2001). Inflammatory cells increase the permeability of blood vessels to expand the membrane, invade, and destroy cartilage and bone (Hitchon \& ElGabalawy, 2011). As the prolonged inflammatory process, fibroblasts destroy the extracellular matrix extracellular matrix (ECM). Chondrocytes stimulate production of proteases, growth factors and inflammatory cytokines which are continue to prolong ECM destruction (Im et al., 2012)
A

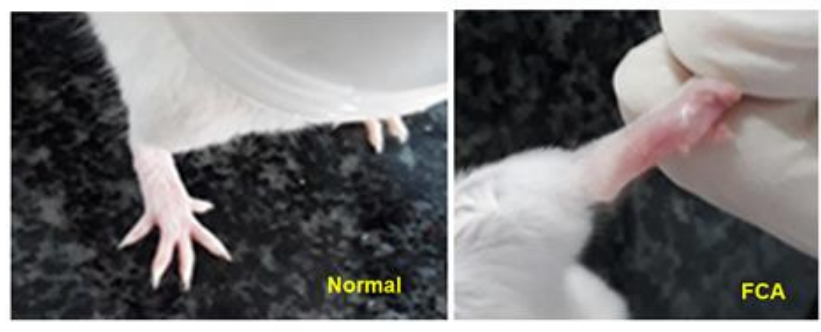

B
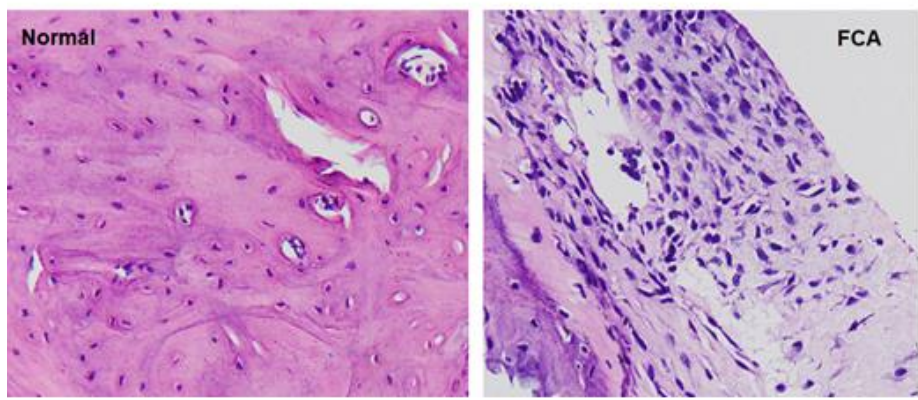

Figure 5 Morphology (A) and histology (B) of ankle of rheumatoid arthritis mice induced by FCA after 12 days. Microscopic appearance of ankle of normal mice. Microscopic appearance of ankle of rheumatoid arthritis mice treated with FCA after 12 days.

At Week 10 after taking AS peel extract and mobic, the shape of ankle joints gradually returned to normal state and was different from untreated mice (Figure 6A). The effect of AS peel extracts on articular histology is illustrated by an ankle joint image that is stained with $\mathrm{H} \& \mathrm{E}$ (Figure 6B). Untreated mice after 10 weeks showed inflammatory extinction, significant increases in fibroblasts, thicker membranes, cell penetration and thin-cartilage formation and cartilage 
erosion. Mice treated with ASL $(200 \mathrm{mg} / \mathrm{kg})$ showed moderate cartilage degradation and infiltration of inflammatory cells only lymphocytes, and restored cartilage shape. With treatment effect of ASM $(300 \mathrm{mg} / \mathrm{kg})$ and ASH $(400 \mathrm{mg} / \mathrm{kg})$, inflammation is reduced, cartilage and basic substance structure are improved without any signs of injury; and inhibits erosion of cartilage. Similar results are also shown in the Mobic group. Histopathological evaluation has demonstrated that AS $(200,300,400 \mathrm{mg} / \mathrm{kg})$ therapy results in a significant reduction of penetration the immune cell and erosion of cartilage, which is in agreement with the study of Shen et al. (2013)

When mice treated with AS, a mixture containing an alkaloid, phenolic acid, phenol, flavonoid are digested by the digestive tract by enzymes or intestinal bacteria and absorbed and transported into the bloodstream to cells, tissues, organs. Polyphenols in the AS participate in beneficial activity transported via the protein channel, absorbed through the membrane into the inflammatory cavity involved in activating cellular responses against inflammatory agents by inhibition of inflammatory factors and cytokine, and suppression of the formation of prostaglandins (Mir \& Agrewala, 2008). Cartilage cells are damaged, which increases the expression of the cell adhesion molecule. Many target polyphenols are the promoters of homeostasis, anti-inflammatory and antioxidant. Polyphenols are resistant to the production of proteolytic enzymes that cause cartilage damage, antioxidants, immune system regulators including B, T cells, macrophages, mast cells and neutrophils (Loeser, 2006).

A
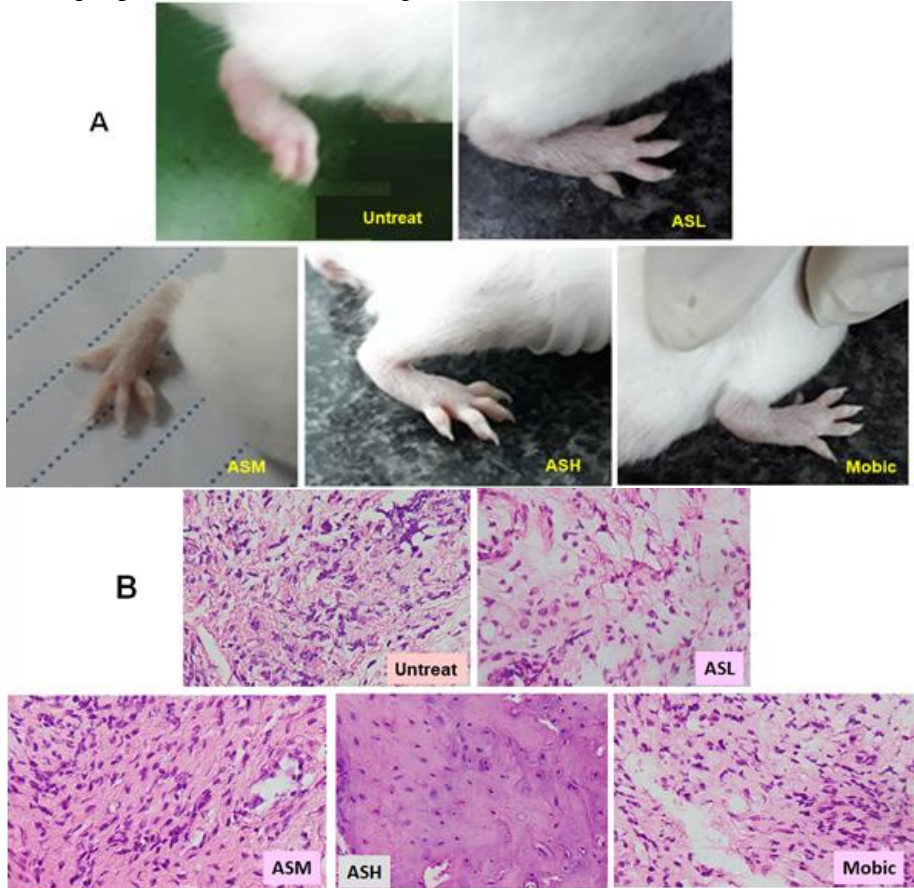

Figure 6 Morphology (A) and histology (B) of ankle of experimental mice. Anatomical analysis ankle of rheumatoid arthritis mice treated with AS after 10 weeks

\section{CONCLUSION}

The fruit peel extract of Annona squamosa L. exhibited anti- rheumatoid arthritis activity by increasing body weight, and by decreasing the temperature and diameter of ankle joint, and levels of leukocytes types in serum of rheumatoid arthritis mice. The histopathology of paw also exhibited reduction in necrosis when treated with the extract. It demonstrated the ameliorative effect of AS peel extracts on treatment of rheumatoid arthritis in mice caused by FCA.

Acknowledgments: The authors wish to thank Duong Thi Thu Thao, Tran Thi Minh Trang, Nguyen Thi Thu Thuy, Tran Thi Hai Yen for their supports and the Institute of Biotechnology and Food-technology, Industrial University of Ho Chi Minh city for their assistance during this project.

Author Contributions: Conceptualization, H.P.T and T.N.T; methodology T.N.T and P.N.T.T; formal analysis, T.N.T and P.N.T.T; investigation, T.N.T and P.N.T.T; resources, T.N.T and H.P.T; writing - original draft preparation, T.N.T and P.N.T.T; writing-review and editing, H.P.T and T.N.T; visualization, T.N.T and P.N.T.T; supervision, H.P.T; project administration, H.P.T.

Funding: This research received no external funding

Conflicts of Interest: The authors declare no conflict of interest.

\section{REFERENCES}

Akramas, L., Leonavičienè, L., Vasiliauskas, A., Bradūnaitè, R., Vaitkienė, D., Zabulytė, D., . . Jonauskienè, I. (2015). Anti-inflammatory and anti-oxidative effects of herbal preparation EM 1201 in adjuvant arthritic rats. Medicina, 51(6), 368-377. doi:https://doi.org/10.1016/j.medici.2015.11.002

Al-Saffar, F. J., Ganabadi, S., Yaakub, H., \& Fakurazi, S. (2009). Collagenase and Sodium Iodoacetate - Induced experimental Osteoarthritis Model in Sprague Dawley Rats. . Asian Journal of Scientific Research, 2(4), 167- 179 doi:https://doi.org/10.3923/ajsr.2009.167.179

Billiau, A., \& Matthys, P. (2001). Modes of action of Freund's adjuvants in experimental models of autoimmune diseases. Journal of Leukocyte Biology, 70(6), 849-860. doi:https://doi.org/10.1189/jlb.70.6.849

Calado, G. P., Lopes, A. J. O., Costa Junior, L. M., Lima, F. d. C. A., Silva, L. A., Pereira, W. S., . . . Nascimento, F. R. F. (2015). Chenopodium ambrosioides L. Reduces Synovial Inflammation and Pain in Experimental Osteoarthritis. PLOS ONE, 10(11), e0141886. doi:https://doi.org/10.1371/journal.pone.0141886 Can, M. V., Nguyen, H. T., Le, T. H., Nguyen, N. T., Do, T. V. N., \& Nguyen, M. T. T. (2016). Anti-inflammatory effects of the bee venom in experimental arthritis rats. Science \& Technology Development, 19(2), 64-70. doi:https://doi.org/10.32508/stdj.v19i2.790

Carlson, R. V., Boyd, K. M., \& Webb, D. J. (2004). The revision of the Declaration of Helsinki: past, present and future. British journal of clinical pharmacology, 57(6), 695-713. doi:https://doi.org/10.1111/j.13652125.2004.02103.x

Chen, Y., Xu, S. S., Chen, J. W., Wang, Y., Xu, H. Q., Fan, N. B., \& Li, X. (2012). Anti-tumor activity of Annona squamosa seeds extract containing annonaceous acetogenin compounds. Journal of Ethnopharmacology. https://doi.org/10.1016/j.jep.2012.05.019

Chen, Y., Chen, Y., Shi, Y., Ma, C., Wang, X., Li, Y., . . . Li, X. (2016) Antitumor activity of Annona squamosa seed oil. Journal of Ethnopharmacology, 193, 362-367. doi:https://doi.org/10.1016/j.jep.2016.08.036

Deng, G. F., Xu, D. P., Li, S., \& Li, H. Bin. (2015). Optimization of ultrasoundassisted extraction of natural antioxidants from sugar apple (Annona squamosa L.) peel using response surface methodology. Molecules, 20(11), 20448-20459. https://doi.org/10.3390/molecules201119708

Halliday, L. C., Artwohl, J. E., Bunte, R. M., Ramakrishnan, V., \& Bennett, T. B. (2004). Effects of Freund's Complete Adjuvant on the Physiology, Histology, and Activity of New Zealand White Rabbits. Journal of the American Association for $\begin{array}{llll}\text { Laboratory Animal } & \text { Science, } & \text { 43(1), }\end{array}$ doi:https://www.ncbi.nlm.nih.gov/pubmed/14984283

Hemalatha, K., \& Satyanarayana, D. (2009). Anti-inflammatory activity of Annona squamosa Linn. Biomedical \& Pharmacology Journal, 2(1), 17-20. doi:http://biomedpharmajournal.org/vol2no1/anti-inflammatory-activity-ofannona-squamosa-linn

Hitchon, C. A., \& El-Gabalawy, H. S. (2011). The synovium in rheumatoid arthritis. The open rheumatology journal, 5, 107-114 doi:https://doi.org/10.2174/1874312901105010107

Hussain, T., Tan, B., Yin, Y., Blachier, F., Tossou, M. C. B., \& Rahu, N. (2016) Oxidative Stress and Inflammation: What Polyphenols Can Do for Us? Oxidative Medicine and Cellular Longevity, 2016, doi:https://doi.org/10.1155/2016/7432797

Im, H.-J., Li, X., Chen, D., Yan, D., Kim, J., Ellman, M. B., . . . van Wijnen, A. J. (2012). Biological effects of the plant-derived polyphenol resveratrol in human articular cartilage and chondrosarcoma cells. Journal of Cellular Physiology, 227(10), 3488-3497. doi:https://doi.org/10.1002/jcp.24049

Janusz, M. J., Bendele, A. M., Brown, K. K., Taiwo, Y. O., Hsieh, L., \& Heitmeyer, S. A. (2002). Induction of osteoarthritis in the rat by surgical tear of the meniscus: Inhibition of joint damage by a matrix metalloproteinase inhibitor. $\begin{array}{llll}\text { Osteoarthritis } \quad \text { and } & \text { Cartilage, } & \text { 10(10), }\end{array}$ doi:https://doi.org/10.1053/joca.2002.0823

Jagtap, U. B., \& Bapat, V. A. (2015). Phenolic composition and antioxidant capacity of wine prepared from custard apple (Annona squamosa L.) Fruits. Journal of Food Processing and Preservation, 39(2), 175-182. https://doi.org/10.1111/jfpp.12219

Jayendra, \& Kumar, Y. (2013). New compound 6,7-dimethoxy-2methylisoquinolinium from Indian medicinal plant Annona squamosa L. International Journal of Chemical and Analytical Science, 4(3), 161-168. https://doi.org/10.1016/j.ijcas.2013.08.005

Kang, S. S., Pak, S. C., \& Choi, S. H. (2002). The Effect of Whole Bee Venom on Arthritis. The American Journal of Chinese Medicine, 30(01), 73-80 doi:https://doi.org/10.1142/s0192415x02000089

Kwon, Y.-b., Lee, J.-d., Lee, H.-j., Han, H.-j., Mar, W.-c., Kang, S.-k., . . . Lee, J.-h. (2001). Bee venom injection into an acupuncture point reduces arthritis associated edema and nociceptive responses. Pain, 90(3), 271-280. doi:https://doi.org/10.1016/S0304-3959(00)00412-7

Lee, J.-D., Kim, S.-Y., Kim, T.-W., Lee, S.-H., Yang, H.-I., Lee, D.-I., \& Lee Y.-H. (2004). Anti-inflammatory Effect of Bee Venom on Type II CollagenInduced Arthritis. The American Journal of Chinese Medicine, 32(03), 361-367 doi:https://doi.org/10.1142/s0192415x04002016 
Linn, S., Linn, S., Sharma, A., Sharma, A. K., Chand, T., \& Khardiya, M. (2013). Preliminary Phytochemical Screening of Fruit Peel Extracts of Annona Original Article Preliminary Phytochemical Screening of Fruit Peel Extracts of Annona. (January).

Loeser, R. F. (2006). Molecular mechanisms of cartilage destruction: Mechanics, inflammatory mediators, and aging collide. Arthritis \& Rheumatism, 54(5), 1357 1360. doi:https://doi.org/10.1002/art.21813

Makay, B., Unsal, E., \& Kasapcopur, O. (2013). Juvenile idiopathic arthritis. World J Rheumatol, 3(3), 16-24. doi:http://dx.doi.org/10.5499/wjr.v3.i3.16

Manach, C., Scalbert, A., Morand, C., Rémésy, C., \& Jiménez, L. (2004). Polyphenols: food sources and bioavailability. The American Journal of Clinical Nutrition, 79(5), 727-747. doi:https://doi.org/10.1093/ajcn/79.5.727

Manners, P. J., \& Bower, C. (2002). Worldwide prevalence of juvenile arthritis why does it vary so much? The Journal of Rheumatology, 29(7), 1520-1530 doi:https://www.ncbi.nlm.nih.gov/pubmed/12136914

McInnes, I. B., \& Schett, G. (2011). The Pathogenesis of Rheumatoid Arthritis New England Journal of Medicine, 365(23), 2205-2219. doi:https://doi.org/10.1056/NEJMra1004965

Mir, M. A., \& Agrewala, J. (2008). Dietary polyphenols in modulation of the immune system Polyphenols In Modulation of the Immune System, . In N. Vassallo (Ed.), Polyphenols and Health: New and Recent Advances (pp. 245 272): Nova Science Publishers.

Morton J.F., 1987. Fruits of warm climates. Pérez-Jiménez J., Saura-Calixto F., 2006. Effect of solvent and certain food constituents on different antioxidant capacity assays. Food Res. Inter. 39, 791-800.

Noble, S., \& Balfour, J. A. (1996). Meloxicam. Drugs, 51(3), 424-430 discussion 431-432. doi:https://doi.org/10.2165/00003495-199651030-00007

O., I. I., Olufunsho, A., Micheal, O. A., \& O., O. C. (2014). Mechanisms of Analgesic and Anti-Inflammatory Properties of Annona muricata Linn. (Annonaceae) Fruit Extract in Rodents. Journal of Medicinal Food, 17(12), 1375-1382. doi:https://doi.org/10.1089/jmf.2013.0088

Pardhasaradhi, B. V. V., Reddy, M., Ali, A. M., Kumari, A. L., \& Khar, A. (2004). Antitumour activity of Annona squamosa seed extracts is through the generation of free radicals and induction of apoptosis. Indian Journal of Biochemistry and Biophysics.

Paul, R., Khanna, A., Gautam, D. S., Bhandari, R., Patel, D., \& Nigam, P. (2018) Effect of aqueous leaf extract of annona squamosa on clarias batrachus fish infected with aeromonas hydrophila with reference to haematological parameters World Journal of Pharmaceutical Reseach, 7(1), 992- 1005 doi:https://doi.org/10.20959/wipr20181-10535

Pearson, C. M. (1956). Development of Arthritis, Periarthritis and Periostitis in Rats Given Adjuvants. Proceedings of the Society for Experimental Biology and Medicine, 91(1), 95-101. doi:https://doi.org/10.3181/00379727-91-22179

Schmelzer, G. H., \& Gurib-Fakim, A. (2008). Medicinal Plants, vol 11. Wageningen, The Netherlands: Plant Resources of Tropical Africa (PROTA). Schurgers, E., Billiau, A., \& Matthys, P. (2011). Collagen-Induced Arthritis as an Animal Model for Rheumatoid Arthritis: Focus on Interferon- $\gamma$. Journal of Interferon \& Cytokine Research, 31(12), 917-926. doi:https://doi.org/10.1089/jir.2011.0056

Shen, L., Wang, P., Guo, J., \& Du, G. (2013). Anti-arthritic activity of ethanol extract of Fagopyrum cymosum with adjuvant-induced arthritis in rats. $\begin{array}{lll}\text { Pharmaceutical } & \text { Biology, } & \text { 783-78), }\end{array}$ doi:https://doi.org/10.3109/13880209.2013.766892

Shirwaikar A., Rajendran K., Dinesh Kumar C., Bodla R., 2004. Antidiabetic activity of aqueous leaf extract of Annona squamosa in streptozotocinnicotinamide type 2 diabetic rats. J. Ethnopharm. 91, 171-175

Singh, T. P., Singh, R. K., \& Malik, P. (2014). Analgesic and anti-inflammatory activities of Annona squamosa Linn bark. Journal of Scientific and Innovative Research, 3(1), 60-64. doi:http://dx.doi.org/10.31254/jsir

Snekhalatha, U., Anburajan, M., Teena, T., Venkatraman, B., Menaka, M., \& Raj, B. (2012). Thermal image analysis and segmentation of hand in evaluation of rheumatoid arthritis. 2012 International Conference on Computer Communication and Informatics, ICCCI 2012, (January). https://doi.org/10.1109/ICCCI.2012.6158784

Stils, H. F., Jr. (2005). Adjuvants and Antibody Production: Dispelling the Myths Associated with Freund's Complete and Other Adjuvants. ILAR Journal, 46(3), 280-293. doi:https://doi.org/10.1093/ilar.46.3.280

Tarahovsky, Y. S., Kim, Y. A., Yagolnik, E. A., \& Muzafarov, E. N. (2014). Flavonoid-membrane interactions: Involvement of flavonoid-metal complexes in raft signaling. Biochimica et Biophysica Acta (BBA) - Biomembranes, 1838(5), 1235-1246. doi:https://doi.org/10.1016/j.bbamem.2014.01.021

Tunon, M. J., Garcia-Mediavilla, M. V., Sanchez-Campos, S., \& GonzalezGallego, J. (2009). Potential of Flavonoids as Anti-inflammatory Agents: Modulation of Pro- Inflammatory Gene Expression and Signal Transduction Pathways. Current Drug Metabolism, 10(3), 256-271. doi:https://doi.org/10.2174/138920009787846369

Yang, Y. L., Hua, K. F., Chuang, P. H., Wu, S. H., Wu, K. Y., Chang, F. R., \& Wu, Y. C. (2008). New cyclic peptides from the seeds of Annona squamosa L. and their anti-inflammatory activities. Journal of Agricultural and Food Chemistry, Vol. 56, pp. 386-392. https://doi.org/10.1021/jf072594w
Yoon, J.-H., \& Baek, S. J. (2005). Molecular Targets of Dietary Polyphenols with Anti-inflammatory Properties. Yonsei Med J, 46(5), 585-596. doi:https://doi.org/10.3349/ymj.2005.46.5.585

Yuan, F., Bai, G., Chen, Y., Miao, Y., Chen, J., \& Li, X. (2015). Structureactivity relationships of diverse ACGs against multidrug resistant human lung cancer cell line A549/Taxol. Bioorganic and Medicinal Chemistry Letters, 25(4) 787-790. https://doi.org/10.1016/i.bmcl.2014.12.088

Zhang, W., J.Zhang, M.Zhang, \& L.Nie. (2014). Protective effect of Asarum extract in rats with adjuvant arthrit. Experimental and Therapeutic Medicine, 8(5), 1638-1642. doi: https://doi.org/10.3892/etm.2014.1941 